\title{
Which risk understandings can be derived from the current disharmonized regulation of complementary and alternative medicine in Europe?
}

Solveig Wiesener ${ }^{1 *} \mathbb{D}$, Anita Salamonsen ${ }^{2}$ and Vinjar Fønnebø ${ }^{1}$

\begin{abstract}
Background: Many European citizens are seeking complementary and alternative medicine (CAM). These treatments are regulated very differently in the EU/EFTA countries. This may demonstrate differences in how risk associated with the use of CAM is perceived. Since most CAM treatments are practiced fairly similarly across Europe, differing risk understandings may influence patient safety for European CAM users. The overall aim of this article is thus to contribute to an overview and awareness of possible differing risk understandings in the field of CAM at a policymaking/structural level in Europe.

Methods: The study is a re-analysis of data collected in the CAMbrella EU FP7 document and interview study on the regulation of CAM in 39 European countries.

The 12 CAM modalities included in the CAMbrella study were ranked with regard to assumed risk potential depending on the number of countries limiting its practice to regulated professions. The 39 countries were ranked according to how many of the included CAM modalities they limit to be practiced by regulated professions.

Results: Twelve of 39 countries generally understand the included CAM treatments to represent "high risk", 20 countries "low risk", while the remaining 7 countries understand CAM treatments as carrying "very little or no risk". The CAM modalities seen as carrying a risk high enough to warrant professional regulation in the highest number of countries are chiropractic, acupuncture, massage, homeopathy and osteopathy.

The countries understanding most of the CAM modalities in the study as potentially high-risk treatments are with two exceptions (Portugal and Belgium) all concentrated in the southeastern region of Europe.

Conclusion: The variation in regulation of CAM may represent a substantial lack of common risk understandings between health policymakers in Europe. We think the discrepancies in regulation are to a considerable degree also based on factors unrelated to patient risk. We argue that it is important for patient safety that policy makers across Europe address this confusing situation. This could be done by applying the WHO patient safety definitions and EU's policy to facilitate access to "safe and high-quality healthcare", and regulate CAM accordingly.
\end{abstract}

Keywords: Risk understanding, Regulation, Risk governance, Risk perception, Health governance, Complementary therapies, Alternative medicine, Traditional medicine, Patient safety, Europe

\footnotetext{
* Correspondence: solveig.wiesener@uit.no

${ }^{1}$ The National Research Center in Complementary and Alternative Medicine

(NAFKAM), Faculty of Health Sciences, Department of Community Medicine,

UiT The Arctic University of Norway, 9037 Tromsø, Norway

Full list of author information is available at the end of the article
}

(c) The Author(s). 2018 Open Access This article is distributed under the terms of the Creative Commons Attribution 4.0 International License (http://creativecommons.org/licenses/by/4.0/), which permits unrestricted use, distribution, and reproduction in any medium, provided you give appropriate credit to the original author(s) and the source, provide a link to the Creative Commons license, and indicate if changes were made. The Creative Commons Public Domain Dedication waiver (http://creativecommons.org/publicdomain/zero/1.0/) applies to the data made available in this article, unless otherwise stated. 


\section{Background}

Many European citizens are seeking a broader spectrum of treatment modalities [1-4]. This includes complementary and alternative medicine (CAM), also when offered outside their national health care system. Users of CAM mostly perceive CAM products and treatments as safe, while health care professionals often express a strong opinion that CAM treatments put patients at risk [5-7].

The World Health Organization (WHO) and the European Union (EU) have both emphasized that the first "rule" of health care is to "not harm" the patient. The WHO patient safety programme states that "the simplest definition of patient safety is the prevention of errors and adverse effects to patients associated with health care" [8]. This understanding underpins all regulation of health care, both of professionals and products, and is taken for granted in the 2011/24/EU Directive "on the application of patients' rights in cross-border healthcare". This directive aims to facilitate access to "safe and high-quality healthcare" for European citizens [9], and patients need to be confident that the treatments offered fulfill these conditions.

Regulation of health services is a risk governance tool for health authorities. The European Union (EU) assumes that a "safe and high quality healthcare" is dependent on a harmonized level of legislation and regulation [9]. The regulation of health care services is not included in the EU Treaty [10] or the 2006/123/EC directive on services in the internal market [11]. The EU Commission has, however, passed the Information document "Conclusions on Common values and principles in European Union Health Systems" to support the EU Member states in their regulation of health care services [12]. The Commission expects that a common set of operating and regulation principles will strengthen "Quality, Safety, Patient involvement and Redress" [12]. Further, the EU Commission emphasizes that regulation of health care must include standardization of treatments and education, recognizable and transparent legislation in all countries, standardized clinical and professional training, together with involvement of patients in their treatment. From a patient safety perspective, the EU Commission promotes regulation of health care as an important governance tool to reduce risk and facilitate high quality health care services for all European citizens.

A large study [13] recently documented that " $C A M$ in Europe is not regulated in accordance with current theory dealing with risk governance, risk regulation and patient safety." In addition, the regulation does not seem to be based on consensual scientific knowledge on effects and risks in CAM practices, efficient risk management in health care governance or systematic reports of harmful events $[5,13-15]$. As a result of this apparent lack of common risk understanding, CAM is regulated "either as conventional, complementary or alternative medicine, or not regulated at all" [13, 16, 17]. Since the treatments themselves are practiced fairly similarly across Europe, this possible differing risk understandings could influence patient safety for European CAM users.

The overall aim of this article is thus to contribute to an overview and awareness of possible differing risk understandings in the field of CAM at a policymaking/ structural level in Europe.

The specific research question is:

Which risk understandings may be derived from the current regulation of CAM in 39 European countries?

\section{Methods}

This study is a re-analysis of data collected in the CAMbrella EU FP7 document and interview study on CAM regulation in Europe [13, 16, 17]. Data dealing with the general legal and regulatory status of CAM on the first and second national legal level, including 12 specific CAM treatment modalities and CAM providers/ professions, were collected from the European Union (EU) and 39 European countries. The included CAM modalities were acupuncture, anthroposophic medicine, ayurvedic medicine, chiropractic, herbal medicine/phytotherapy, homeopathy, massage, naprapathy, naturopathy, neural therapy, osteopathy and Traditional Chinese Medicine (TCM).

The 12 CAM modalities included in the CAMbrella study were in this study ranked with regard to assumed risk potential depending on the number of countries limiting practice of CAM modalities to regulated professions. We ranked the 39 countries according to how many CAM modalities they limit to regulated professions. We have arbitrarily classified countries limiting 5 or more of 12 CAM modalities to regulated professions as seeing CAM as high-risk treatment approaches, and regulating $1-4$ as seeing $\mathrm{CAM}$ as carrying a potential low patient risk. If a country has not limited any modality to a regulated profession, we classify the country as seeing CAM with very little or no risk.

\section{Results}

We found that 12 countries understand the included CAM treatments as carrying a high risk, 20 understand the CAM treatments to have low risk, while the remaining 7 countries generally understand the CAM treatments to be with very little or no risk (Fig. 1). We also found that countries understanding CAM to be associated with low, very little or no risk, only regulate modalities that are the most commonly regulated in the countries with a high-risk understanding. There are, 


\section{European country specific regulation of 12 CAM modalities- risk understanding}

\begin{tabular}{|c|c|c|c|c|c|c|c|c|c|c|c|c|}
\hline & Chiro & Acu & Massa & Homeo & Oste & TCM & Anthrop & Herbal & Naturo & Ayurved & Neural & Napra \\
\hline \multicolumn{13}{|l|}{ Hungary } \\
\hline \multicolumn{13}{|l|}{ Romania } \\
\hline \multicolumn{13}{|l|}{ Portugal } \\
\hline \multicolumn{13}{|l|}{ Austria } \\
\hline \multicolumn{13}{|l|}{ Liechtenstein } \\
\hline \multicolumn{13}{|l|}{ Switzerland } \\
\hline \multicolumn{13}{|l|}{ Bulgaria } \\
\hline \multicolumn{13}{|l|}{ Serbia } \\
\hline \multicolumn{13}{|l|}{ Slovenia } \\
\hline \multicolumn{13}{|l|}{ Turkey } \\
\hline \multicolumn{13}{|l|}{ Belgium } \\
\hline \multicolumn{13}{|l|}{ Italy } \\
\hline \multicolumn{13}{|l|}{ France } \\
\hline \multicolumn{13}{|l|}{ Latvia } \\
\hline \multicolumn{13}{|l|}{ Czech republic } \\
\hline \multicolumn{13}{|l|}{ Finland } \\
\hline \multicolumn{13}{|l|}{ Iceland } \\
\hline \multicolumn{13}{|l|}{ Lithuania } \\
\hline \multicolumn{13}{|l|}{ Malta } \\
\hline \multicolumn{13}{|l|}{ Spain } \\
\hline Sweden & & & & & & & & & & & & \\
\hline Germany & & & & & & & & & & & & \\
\hline UK & & & & & & & & & & & & \\
\hline Estonia & & & & & & & & & & & & \\
\hline Slovakia & & & & & & & & & & & & \\
\hline Luxembourg & & & & & & & & & & & & \\
\hline Cyprus & & & & & & & & & & & & \\
\hline Denmark & & & & & & & & & & & & \\
\hline Greece & & & & & & & & & & & & \\
\hline Poland & & & & & & & & & & & & \\
\hline Israel & & & & & & & & & & & & \\
\hline Norway & & & & & & & & & & & & \\
\hline Albania & & & & & & & & & & & & \\
\hline Croatia & & & & & & & & & & & & \\
\hline Macedonia & & & & & & & & & & & & \\
\hline Bosnia\&Herzegovina & & & & & & & & & & & & \\
\hline Ireland & & & & & & & & & & & & \\
\hline Montenegro & & & & & & & & & & & & \\
\hline The Netherlands & & & & & & & & & & & & \\
\hline & Treatm & ent is I & ited to $\mathrm{h}$ & ealth pro & fessior & & & & & & & \\
\hline & Treatm & ent is $r$ & ulated, & ut not lin & nited $t$ & health & rofessions & & & & & \\
\hline & Countr & es limi & $\lg 5$ or $\mathrm{m}$ & ore moda & alities t & regulat & d professi & ions & & & & \\
\hline & Countr & es limi & g 1-4 mc & dalities $t$ & o regu & ted pro & essions & & & & & \\
\hline & Countr & es limi & ig none 1 & nodalities & s to re & lated $p$ & ofessions & & & & & \\
\hline $\begin{array}{l}\text { Acu = Acupuncture, Antl } \\
\text { medicine/Phytotherapy, } \\
\text { therapy, Oste = Osteopat }\end{array}$ & $\begin{array}{l}\mathrm{p}=\text { Ant } \\
\text { meo }=1 \\
\mathrm{TCM}=\end{array}$ & $\begin{array}{l}\text { iropos } \\
\text { omeo } \\
\text { raditio }\end{array}$ & $\begin{array}{l}\text { hic med } \\
\text { thy, Mas } \\
\text { Chines }\end{array}$ & $\begin{array}{l}\text { ine }, \text { Ayu } \\
\text { sa }=\text { Mas } \\
\text { Medicin }\end{array}$ & $\begin{array}{l}\text { Arved } \\
\text { sage, I } \\
\text { e }\end{array}$ & $\begin{array}{l}\text { Ayurve } \\
\text { apra }=1\end{array}$ & $\begin{array}{l}\text { lic medicin } \\
\text { aprapathy, }\end{array}$ & $\begin{array}{l}\text { ne, Chir } \\
\text {, Natur }\end{array}$ & $=$ Chiro & opractic. 1 & Herbal $=$ & $\begin{array}{l}\text { Herbal } \\
\text { Neural }\end{array}$ \\
\hline
\end{tabular}

Fig. 1 European country specific regulation of 12 CAM modalities-risk understanding 
however, two country exceptions worth noting; Finland and Sweden also regulate naprapaths.

The CAM modalities seen as carrying a risk high enough to warrant professional regulation in the highest number of countries are chiropractic, acupuncture, massage, homeopathy and osteopathy. The "manual" therapies (naprapathy, massage, osteopathy and chiropractics) are almost exclusively regulated as specific health professions with protected titles in the countries that have chosen to regulate.

The countries that seem to understand CAM treatment to be associated with a potentially high patient risk are not randomly distributed across Europe. With two exceptions (Portugal and Belgium), they are all concentrated in the southeastern region of Europe (Fig. 2).

\section{Discussion}

This study demonstrates that the regulation of CAM indicates the differences in how the European health authorities may perceive risk associated with the use of CAM.

We do not extrapolate our findings beyond the 39 countries studied, and there is therefore no selection bias in this study with regard to countries. The

\section{nafkam}

The National Research Center in Complementary and Alternative Medicine

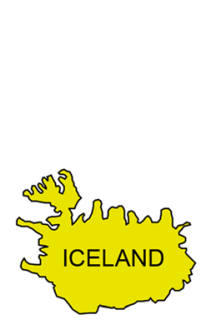

Number of regulated CAM professions

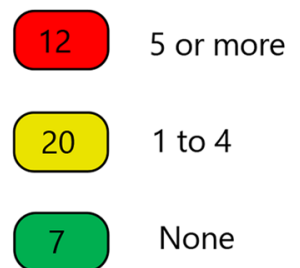

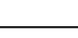


procedure followed to gain overview of the regulatory situation was comprehensive $[13,16,17]$, and the regulation in each country is constantly being updated [18]. To our information, no one has successfully contested our descriptions, and the information presented is therefore likely to be unbiased.

To our knowledge, no one has previously described international CAM regulation in a risk perspective focusing on risk understanding.

In the introduction to the 2011/24/EU Directive "on the application of patients' rights in cross-border healthcare", the European Council assumes that "safe and high-quality healthcare" is in place when declaring that there "is a set of operating principles that are shared by health systems throughout the Union" (Directive 2011/24/EU Directiveintroduction note 5) [9]. The most common used "operating principles" in providing safe and high-quality healthcare are to regulate the professional requirements of health providers and standardization of treatments [13]. Baldwin claims that "..regulation is often thought of as an activity that restricts behavior and prevents the occurrence of certain undesirable activities" [19].

Previous studies show that conventional healthcare is regulated quite similarly across Europe. Core health professionals are defined as "Sectorial professions" benefiting from automatic recognition on the basis of harmonization of minimum training conditions (doctors, nurses, midwives, pharmacists and dentists) $[13,20]$. High quality and safety are perceived as established through appropriate research and sound professional standards, at the same time as attractive treatment options across borders are available [21].

We would have expected to find similar sets of operating principles in the regulation of CAM. The most regulated CAM modality in Europe is chiropractic. Does this mean that chiropractic treatment is associated with such a high patient risk that 25 European countries see strong regulation as necessary, or could the regulation be based on other criteria as well? A closer look at the process of regulating chiropractors in Norway in 1988 sheds light on this possibility [22]. The decision to regulate was based on a 1985 governmental report. The arguments for giving chiropractors authorization and a protected title were to secure the educational requirements for practicing chiropractic. The politicians stated that regulation of chiropractors would strengthen the profession and lead to recognition of the chiropractors as health professionals, nothing about risk [23].

Taking acupuncture regulation as an additional example, we found no consistent pattern of risk understanding. Acupuncture treatment is the second most regulated CAM modality in Europe, but only 3 countries have established "acupuncturist" as a profession. In Hungary 3-5 years of acupuncture education/training at a university level is required in addition to being a medical doctor. In Norway acupuncture can be legally practiced without any educational requirements whatsoever. Based on our classification, acupuncture is understood to be a high-risk treatment in Hungary, while Norwegian health authorities seem to understand the same treatment to be without risk. The "high-risk" regulation in Hungary could possibly be based on registered adverse events, number of harmed patients and claims, combined with risk or effect research. If so, why do they not take into account this risk information in the "no-risk" regulation in Norway?

An interesting example of risk understanding linked to the importance of professional knowledge is the regulation of homeopathy in Belgium. The "Belgian Healthcare Knowledge Centre" stated in a public report in 2011 that due to safety reasons, homeopathy should be restricted to physicians, dentists and veterinary doctors [24]. Consequently, "The Belgian Council of Ministers passed new regulation on homeopathy in 2013, made official by a Royal Decree published 12 May 2014 by the Ministry of Health" [18]. This decision is consistent with Belgian regulation of other common CAM practices (Fig. 1 European country specific regulation of 12 CAM modalities-risk understanding). We hypothesize that the risk perception of the Belgian health authorities is of an "indirect" nature.

\section{Regulation of CAM- a decision model}

Risk associated with health care is often separated into direct risk caused by the treatment itself or indirect risk related to adverse effects of the treatment context [15]. The discrepancies in regulatory practice between countries are, in our view, only explicable if factors other than direct or indirect risk are taken into consideration. Based on the regulation status across Europe, as well as established risk and health management research and legislation, we have developed a theoretical decision model we think more truly reflects the political process relevant for the regulation of CAM (Fig. 3).

The model includes multiple factors that come into play when a country considers the regulation of CAM, and the chosen level of regulation will reflect the factors given most importance.

The map showing CAM regulation presented in this article (Fig. 2) illustrates the potential importance of national and/or regional traditions. This was already suggested by Gerd Ersdal 12 years ago [25]. She divided European countries into "all-regulated" and "semi-regulated" systems of CAM regulation, and suggested that this geographical megapattern seemed to indicate that in the middle and south of Europe CAM regulation followed the principle: "if regulated-it is allowed". In northern Europe the principle "if not forbidden by law- 


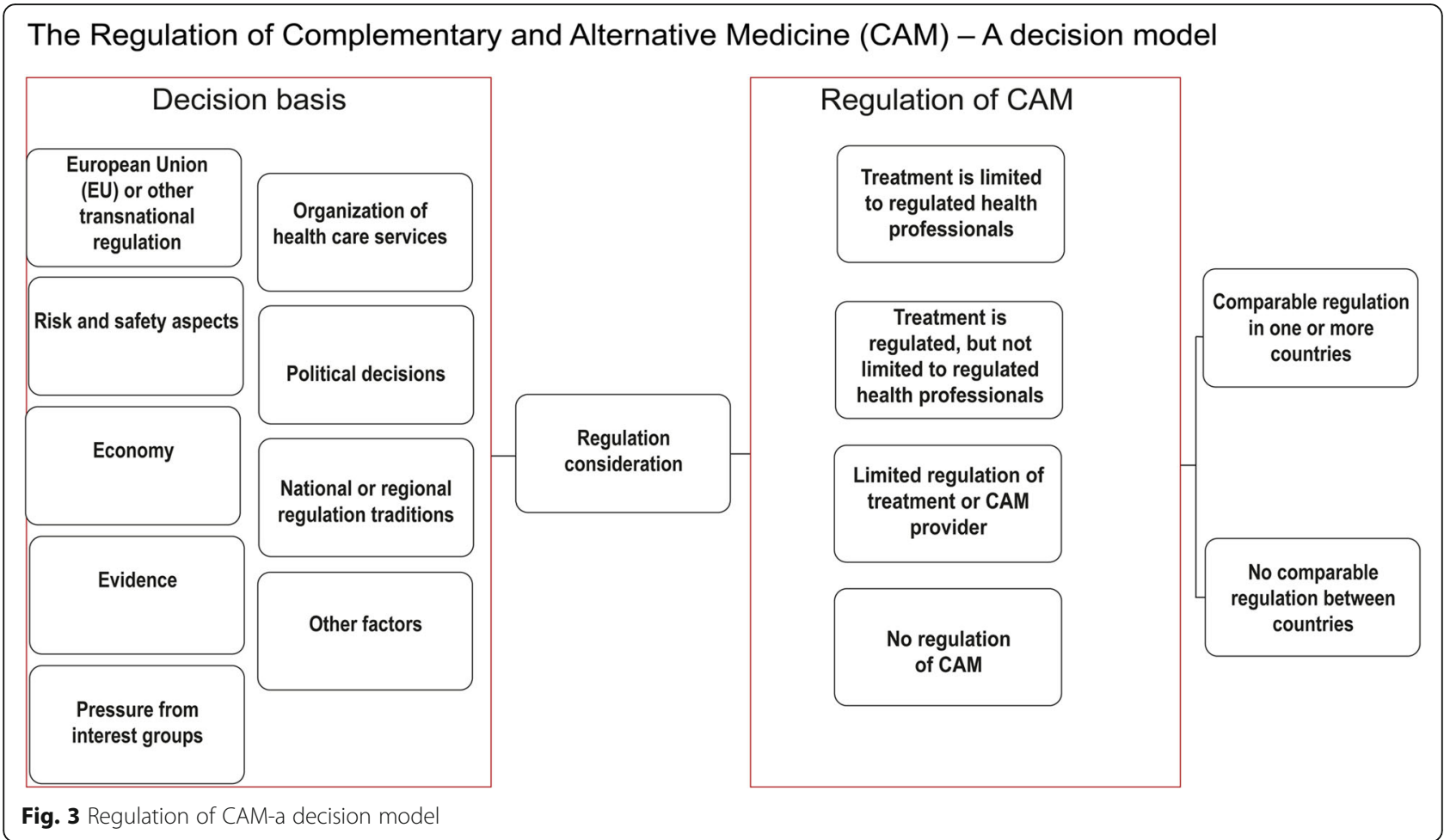

it is allowed" seemed to dominate. But even within these regions the regulations of CAM varies substantially. It is difficult to understand the basis for why they have regulated the way they have done.

\section{Conclusion}

The variation in regulation of CAM may represent a substantial lack of common risk understandings between health policymakers in Europe. We think the discrepancies in regulation are to a considerable degree also based on factors unrelated to patient risk. We argue that it is important for patient safety that policy makers across Europe address this confusing situation. This could be done by applying the WHO patient safety definitions and EU's policy to facilitate access to "safe and high-quality healthcare", and regulate CAM accordingly.

\section{Abbreviations}

CAM: Complementary and alternative medicine; EFTA: The European Free Trade Association; EU: The European Union; WHO: The World Health Organization

\section{Acknowledgements}

We thank Tine Lillegård Bergli at The National Research Center in Complementary and Alternative Medicine (NAFKAM) for her technical assistance. The publication charges for this article have been funded by a grant from the publication fund of UiT The Arctic University of Norway.

\section{Funding}

No external funding was received.
Availability of data and materials

The CAMbrella EU reports are available at http://phaidra.univie.ac.at/o:291583, http://phaidra.univie.ac.at/o:291584 and http://phaidra.univie.ac.at/o:291585 Updated data after CAMbrella deliveries are available at http://nafkamcamregulation.uit.no/.

Authors' contributions

SW and AS drafted the initial version of the paper, SW and VF performed the initial analyses of the country specific data. All authors reviewed subsequent versions, and read and approved the final manuscript.

Ethics approval and consent to participate Not applicable.

Consent for publication

Not applicable.

Competing interests

The authors declare that they have no competing interests.

\section{Publisher's Note}

Springer Nature remains neutral with regard to jurisdictional claims in published maps and institutional affiliations.

\section{Author details}

${ }^{1}$ The National Research Center in Complementary and Alternative Medicine (NAFKAM), Faculty of Health Sciences, Department of Community Medicine, UiT The Arctic University of Norway, 9037 Tromsø, Norway. ${ }^{2}$ Regional Centre for Child and Youth Mental Health and Child Welfare (RKBU North), Faculty of Health Sciences, UiT The Arctic University of Norway, 9037 Troms $\varnothing$, Norway. 
Received: 20 June 2017 Accepted: 28 December 2017

\section{Published online: 10 January 2018}

\section{References}

1. Molassiotis A, Fernadez-Ortega P, Pud D, Ozden G, Scott JA, Panteli V, Margulies A, Browall M, Magri M, Selvekerova S, et al. Use of complementary and alternative medicine in cancer patients: a European survey. Ann Oncol. 2005;16(4):655-63. https://doi.org/10.1093/annonc/mdi110.

2. Zuzak TJ, Bonkova J, Careddu D, Garami M, Hadjipanayis A, Jazbec J, Merrick J, Miller J, Ozturk C, Persson IA, et al. Use of complementary and alternative medicine by children in Europe: published data and expert perspectives. Complement Ther Med. 2013;21(Suppl 1):34-47. https://doi.org/10.1016/j. ctim.2012.01.001.

3. Frass M, Strassl RP, Friehs H, Mullner M, Kundi M, Kaye AD. Use and acceptance of complementary and alternative medicine among the general population and medical personnel: a systematic review. Ochsner J. 2012; 12(1):45-56.

4. Eardley S, Bishop FL, Prescott P, Cardini F, Brinkhaus B, Santos-Rey K, Vas J, von Ammon K, Hegyi G, Dragan S, et al. A systematic literature review of complementary and alternative medicine prevalence in EU. Forsch Komplementmed (2006). 2012;19(Suppl 2):18-28. https://doi.org/10.1159/ 000342708.

5. Wardle $\mathrm{J}$, Adams J. Indirect and non-health risks associated with complementary and alternative medicine use: an integrative review. Eur J Intern Med. 2014;6(4):409-22. http://dx.doi.org/10.1016/j.eujim.2014.01.001.

6. Salamonsen A, Wiesener S. Are differing risk perceptions related to patients' use of CAM a barrier to doctor-patient communication in comprehensive patient care. Poster: world congress integrative medicine \& health 2017. BMC Complement Altern Med. 2017;17(suppl 1):170.

7. Robinson A, McGrail MR. Disclosure of CAM use to medical practitioners: a review of qualitative and quantitative studies. Complement Ther Med. 2004; 12(2-3):90-8. https://doi.org/10.1016/j.ctim.2004.09.006.

8. World Health Organization. Patient Safety. http://www.euro.who.int/en/ health-topics/Health-systems/patient-safety. Accessed 19 June 2017.

9. The European Parliament and the Council. DIRECTIVE 2011/24/EU OF THE EUROPEAN PARLIAMENT AND OF THE COUNCIL of 9 March 2011, on the application of patients' rights in cross-border healthcare (OJ | 88, 4.4.2011, p.45). In: Official journal L 088, 04/04/2011 P 0045-0065. Brussels: The European Union; 2011.

10. The European Union. Treaty of Lisbon amending the treaty on European Union and the treaty establishing the European Community, signed at Lisbon, 13 December 2007, entered into force December 1, 2009. In: OJ C 306 17122007. Brussels: The European Union; 2007. p. 01

11. The European Parliament and the Council of the European Union. DIRECTIVE 2006/123/EC OF THE EUROPEAN PARLIAMENT AND OF THE COUNCIL of 12 December 2006 on services in the internal market. In: OJ L 376, 27122006. Brussels: The European Union; 2006. p. 36.

12. The Council of the European Union. 2006/C 146/01 Council conclusions on common values and principles in European Union health systems. In: OJ C 146/1 2262006. eur-lex.europe.eu: Official Journal of the European Union; 2006.

13. Wiesener S. Disharmonized regulation of Complementary and Alternative Medicine (CAM) in Europe-implications for patients safety. Master thesis. University of Stavanger; 2013. http://hdl.handle.net/11250/184765.

14. Salamonsen A. Mind the gap! Lay and medical perceptions of risks associated with the use of alternative treatment and conventional medicine. Forsch Komplementmed. 2015;22(1):24-9. https://doi.org/10.1159/000376555.

15. Stub T, Quandt SA, Arcury TA, Sandberg JC, Kristoffersen AE, Musial F, Salamonsen A. Perception of risk and communication among conventional and complementary health care providers involving cancer patients' use of complementary therapies: a literature review. BMC Complement Altern Med. 2016;16:353. https://doi.org/10.1186/s12906-016-1326-3.

16. Wiesener S, Falkenberg T, Hegyi G, Hök J, Roberti di Sarsina P, Fønnebø V. Legal status and regulation of complementary and alternative medicine in Europe. In: Forschende Komplementarmedizin (2006), vol. 19; 2012. p. 29-36. https://doi.org/10.1159/000343125.

17. Wiesener S, Falkenberg T, Hegyi G, Hök J, Roberti di Sarsina P, Fønnebø V. Deliverable 9-reports no. 1, 2 and 3; CAMbrella project FP7-HEALTH-2009, GA no.241951; work package 2; deliverable 9-legal status and regulation of CAM in Europe. In: CAMbrella. Brussels: EU; 2012. http://phaidra.univie. ac.at/o:291583; http://phaidra.univie.ac.at/o:291584; http://phaidra.univie. ac.at/o:291585.
18. Wiesener S. CAM regulation. The National Research Center in Complementary and Alternative Medicine (NAFKAM). http://nafkamcamregulation.uit.no/. Accessed 15 June 2017.

19. Baldwin $\mathrm{R}$, Cave M, Lodge M. Understanding regulation: theory, strategy, and practice. 2nd ed. Oxford: Oxford University Press; 2012.

20. The European Parliament and the Council of the European Union. DIRECTIVE 2005/36/EC OF THE EUROPEAN PARLIAMENT AND OF THE COUNCIL of 7 September 2005 on the recognition of professional qualifications (text with EEA relevance). In: OJ L 255, 3092005. Brussels: The European Union; 2005. p. 22.

21. Braut GS. The requirement to practice in accordance with sound professional standards. In: Molven O, Ferkis J, editors. Healthcare, welfare and law: health legislation as a mirror of the Norwegian welfare state. 1st ed. Oslo: Gyldendal Akademisk; 2011. p. 139-49.

22. LOV-1999-07-02-64 Lov om helsepersonell m.v. (helsepersonelloven- hlspl) English: Act 1999-07-02-64. Act relating to health personnel etc., HOD (Helse-og Omsorgsdepartementet; 1999. https://lovdata.no/dokument/NL/ lov/1999-07-02-64

23. Sosialdepartementet. St.meld.nr 70 (1986-87) Om autorisasjon av kiropraktorer. Særskilt vedlegg NOU 1985: 10: Autorisasjon av kiropraktorer. In: Edited by Sosialdepartementet. Oslo: Statens forvaltningstjeneste; 1985/1987.

24. The Belgian Health Care Knowledge Centre (KCE). Stand van zaken van de homeopathie in België (KCE reports 154A). In: Edited by The Minister of Public Health and Social Affairs. Brussels: Belgian Health Care Knowledge Centre; 2011.

25. Ersdal G, CAM-CANCER consortium. How are European patients safeguarded when using complementary and alternative medicine (CAM)? Jurisdiction, supervision and reimbursement status in the EEA area (EU and EFTA) and Switzerland. In: Report CAM 211105-1doc. Tromsø: NAFKAM, University of Tromsø; 2005. p. 53

\section{Submit your next manuscript to BioMed Central and we will help you at every step:}

- We accept pre-submission inquiries

- Our selector tool helps you to find the most relevant journal

- We provide round the clock customer support

- Convenient online submission

- Thorough peer review

- Inclusion in PubMed and all major indexing services

- Maximum visibility for your research

Submit your manuscript at www.biomedcentral.com/submit
C Biomed Central 